\title{
PENENTUAN BIAYA KECELAKAAN LALU LINTAS: STUDI KASUS LOMBOK TIMUR
}

\author{
Determination of Traffic Accident Costs: Case Study of East Lombok
}

\author{
Andyka Kusuma \\ Departemen Teknik Sipil \\ Universitas Indonesia \\ Kampus Baru UI \\ Depok, Jawa Barat \\ andyka.k@eng.ui.ac.id
}

\author{
Tri Tjahjono \\ Departemen Teknik Sipil \\ Universitas Indonesia \\ Kampus Baru UI \\ Depok, Jawa Barat \\ tjahjono@eng.ui.ac.id
}

\author{
Nuzul Achjar \\ Departemen Teknik Sipil \\ Universitas Indonesia \\ Kampus Baru UI \\ Depok, Jawa Barat \\ achjar@gmail.com
}

\begin{abstract}
Traffic accident cost analysis is needed to predict potential losses of nation due to the emergence of traffic accident victims. The cost of traffic accidents in Indonesia is based on the characteristics of the City of Bandung in 2003, and it is shown that the cost of traffic accidents can vary according to regional characteristics. This study tries to compare the analytical approach in Bandung in 2003 with the Consumer Price Index and Human Development Index approaches for an area with medium accessibility, namely East Lombok, West Nusa Tenggara Province. The location of traffic accidents greatly influences the cost of traffic accidents, because the costs on inter-city roads are relatively higher compared to those on roads in the city. This study shows that the cost of traffic accidents is related to accessibility of health facilities. This analysis can be developed for all regions in Indonesia, so that it can be used as a reference for traffic stakeholders in assessing the performance of the traffic safety programs implemented
\end{abstract}

Keywords: traffic accident costs, traffic accident locations, accessibility of health facilities

\begin{abstract}
Abstrak
Analisis biaya kecelakaan lalu lintas diperlukan untuk memprediksi potensi kerugian negara akibat timbulnya korban kecelakaan lalu lintas. Biaya kecelakaan lalu lintas di Indonesia dibangun berdasarkan karakteristik kota Bandung tahun 2003, dan diperlihatkan bahwa biaya kecelakaan lalu lintas dapat bervariasi sesuai dengan karakteristik wilayah. Penelitian ini mencoba membandingkan pendekatan analisis di Bandung tahun 2003 dengan pendekatan Indeks Harga Konsumen dan Indeks Pembangunan Manusia untuk suatu wilayah dengan aksesibilitas menengah, yakni Lombok Timur, Provinsi Nusa Tenggara Barat. Lokasi kecelakaan lalu lintas sangat mempengaruhi biaya kecelakaan lalu lintas, karena biaya di jalan antar kota relatif lebih tinggi dibandingkan dengan biaya di jalan dalam kota. Penelitian ini meperlihatkan bahwa biaya kecelakaan lalu lintas terkait dengan aksesibilitas fasilitas kesehatan. Analisis ini dapat dikembangkan untuk semua wilayah di Indonesia, sehingga dapat dijadikan acuan bagi pemangku kepentingan lalu lintas dalam menilai kinerja program keselamatan lalu lintas yang dijalankan
\end{abstract}

Kata Kunci: biaya kecelakaan lalu lintas, lokasi kecelakaan lalu lintas, aksesibilitas fasilitas kesehatan

\section{PENDAHULUAN}

Berdasarkan data dari Jasa Raharja dan Kepolisian Republik Indonesia, jumlah kecelakaan lalu lintas selama 5 tahun terakhir mencapai lebih dari 105 ribu kasus, yang terdapat pada aplikasi data kecelakaan lalu lintas nasional Indonesia, yang dikenal dengan Integrated Road Safety Management System atau IRSMS (Yahya et al., 2013). Dengan populasi sekitar 261 juta orang, sebagian besar korban kecelakaan lalu lintas adalah kaum muda usia produktif, dengan usia antara (15-29) tahun (IRSMS, 2017). Perusahaan asuransi Jasa Raharja telah memberikan kompensasi kepada korban atau keluarga korban, yang 
mencapai Rp. 6,6 triliun atau sekitar Rp. 1,4 triliun setiap tahun rata-rata. Tingginya angka kecelakaan lalu lintas ini juga dipengaruhi oleh tingginya jumlah kendaraan, yang mencapai lebih dari 120 juta unit. Faktor manusia menyumbang $90 \%$ kecelakaan lalu lintas, sementara $10 \%$ lainnya disebabkan oleh faktor-faktor jalan, rambu lalu lintas, dan kendaraan (WHO, 2015).

Secara konseptual, kecelakaan lalu lintas membebani ekonomi karena aspek keuangan dan non-keuangannya. Karena itu dapat dipahami jika Perserikatan Bangsa-Bangsa (PBB) menetapkan tahun 2011 hingga tahun 2020 sebagai Tahun Aksi untuk Keselamatan Lalu Lintas atau Dekade Aksi untuk Keselamatan Jalan. Kampanye ini ditargetkan untuk mengurangi jumlah kecelakaan lalu lintas di dunia hingga $50 \%$.

Sakhapov dan Nikolaeva (2017) menunjukkan bahwa terdapat hubungan positif antara Pendapatan Nasional Bruto (PNB) per kapita dengan jumlah kendaraan bermotor di suatu negara. Selain itu, terdapat pula hipotesis bahwa akan ada hubungan positif antara PNB per kapita dan jumlah kecelakaan lalu lintas yang menyebabkan kematian atau cedera.

Provinsi Nusa Tenggara Barat, yang terdiri atas 10 kabupaten dan kota, adalah salah satu provinsi di Indonesia yang mencatat pertumbuhan ekonomi rata-rata $4 \%$ setiap tahun. Ke depan, dengan kegiatan ekonomi yang berkembang, jumlah kendaraan serta risiko kecelakaan lalu lintas diprediksi akan tumbuh lebih besar. Selama 2016 hingga April 2017, telah terjadi lebih dari 3.300 kecelakaan lalu lintas yang menewaskan 669 orang, 317 lukaluka, dan 2.644 luka ringan. Korban tewas tersebut didominasi oleh usia muda produktif, yang berumut antara (20-30) tahun.

Di tingkat kabupaten dan kota, terdapat indikasi bahwa kecelakaan lalu lintas lebih banyak terjadi di Lombok Timur. Kerusakan jalan di pedesaan, berupa tumbuhnya rerumputan liar di pinggir jalan, retakan, dan lubang pada jalan, merupakan masalah serius dan salah satu penyebab kecelakaan lalu lintas di Indonesia, sehingga perlu untuk dikembangkan dan dipelihara. Kontruksi awal yang buruk dan kurangnya pemeliharaan menyebabkan terjadinya kerusakan jalan yang cepat. Untuk perbaikan jalan, biaya rekonstruksi diperkirakan 3 hingga 5 kali lebih tinggi dibandingkan dengan biaya pemeliharaan. Hal ini sering diabaikan, sehingga banyak pemerintah daerah yang hanya memusatkan pengeluaran untuk pembangunan jalan-jalan baru dan mengabaikan pemeliharaan. Salah satu provinsi di Indonesia yang mengalami masalah demikian adalah Provinsi Nusa Tenggara Barat (NTB). Oleh sebab itu, studi ini bertujuan untuk menganalisis biaya kecelakaan lalu lintas, terutama untuk kecelakaan lalu lintas yang terjadi di wilayah kabupaten. Pemilihan Kabupaten Lombok Timur, Provinsi NTB, sebagai lokasi studi bertujuan untuk melihat variansi untuk kabupaten atau wilayah yang relatif jauh dari ibu kota propinsi.

\section{KAJIAN LITERATUR}

\section{Applikasi dari Cost Benefit Analysis dalam Keselamatan Jalan}

Kebijakan keselamatan jalan bertujuan untuk mengurangi jumlah kecelakaan dan jumlah korban karena kecelakaan lalu lintas. Salah satu metode yang dapat digunakan untuk mengukur efektivitas kebijakan keselamatan jalan adalah analisis biaya-manfaat. Metode ini secara eksplisit menetapkan nilai uang untuk kehidupan manusia, sehingga pembuat 
kebijakan dapat membandingkan keuntungan menyelamatkan nyawa manusia dengan efek dan biaya lainnya (Wijnen, Wesemann dan de Blaeij, 2009)

Cost-Benefit Analysis (CBA) adalah suatu metode konvensional untuk menganalisis indikator kinerja keselamatan jalan. Aspek manfaat kebijakan keselamatan jalan biasanya dilihat pada penurunan jumlah kecelakaan lalu lintas dan korban jiwa, sedangkan aspek biaya dapat dilihat pada investasi yang telah dikeluarkan, waktu yang hilang, dan bahkan hilangnya kebebasan (Hauer, 1997). Gitelman and Shalom Hakkert (2011) membagi efek kebijakan keselamatan jalan ke dalam 5 aspek, yaitu rumus dasar, efek keamanan, biaya kecelakaan, unit dan biaya implementasi, serta efek samping.

Rumus dasar yang digunakan dalam mengukur CBA dalam kebijakan keselamatan jalan dapat dirumuskan sebagai:

$$
x=x^{\prime} \cdot p
$$

dimana: $x$ : Potensi jumlah kecelakaan yang dapat dicegah akibat suatu kebijakan program keselamatan

$x^{\prime}$ : Jumlah kecelakaan yang dapat terjadi per tahun

$k$ : Safety factor suatu kebijakan

Biaya kecelakaan secara umum dapat dibagi menjadi 5 elemen, yaitu biaya medis, biaya produksi yang hilang, penilaian kualitas hidup yang hilang, biaya kerusakan properti, dan biaya administrasi. Biaya kecelakaan dapat diperkirakan dengan konsep yang disebut dengan Nilai Kehidupan Statistik, yang akan dijelaskan di bagian selanjutnya.

Unit dan biaya pelaksanaan bergantung pada kebijakan yang akan dianalisis. Dalam konteks infrastruktur, unit pelaksana biasanya jalan 1 kilometer. Ini berbeda dengan pengukuran keamanan mengemudi, yang unit pelaksananya dapat berupa 1 unit kendaraan. Biaya pelaksanaan adalah biaya sosial semua biaya produksi, yaitu tenaga kerja dan modal, yang dikenakan untuk menerapkan kebijakan (Gitelman dan Shalom Hakkert, 2011). Biaya implementasi, termasuk biaya investasi dan biaya operasi serta biaya pemeliharaan tahunan, perlu dikonversi ke nilai sekarang.

Efek samping kebijakan keselamatan jalan dapat menghasilkan 3 jenis efek, yaitu keamanan, mobilitas, dan lingkungan. Efek mobilitas berdampak pada perubahan waktu perjalanan dan biaya pemeliharaan kendaraan, sedangkan dampak lingkungan berupa emisi dan kebisingan.

Perlu dicatat bahwa dalam menerapkan metode ini akan ada kemungkinan mengubah perilaku pengendara ketika ada kebijakan yang terkait dengan keselamatan di jalan. Jalan dan mobil yang lebih aman akan cenderung mendorong perilaku mengemudi menjadi lebih berbahaya. Perubahan perilaku ini tidak sepenuhnya menghilangkan keuntungan keamanan yang berasal dari implementasi kebijakan tetapi mengurangi efektivitas program keselamatan jalan dalam beberapa kasus.

\section{Value of Statistical Life}

Value of Statistical Life (VoSL) adalah nilai yang dibayar oleh individu untuk mengurangi probabilitas risiko kematian (Wijnen, Wesemann dan de Blaeij, 2009). VSL tidak mengacu pada nilai spesifik kehidupan manusia, tetapi pada evaluasi risiko yang akan mengakibatkan hilangnya nyawa manusia. Secara umum, biaya kecelakaan dibagi menjadi 3 komponen, yaitu: a) Biaya ekonomi langsung, seperti biaya medis, biaya rehabilitasi, dan 
administrasi; b) Biaya ekonomi tidak langsung, seperti biaya yang dirasakan oleh seluruh masyarakat karena hilangnya produktivitas karena kecelakaan; dan c) biaya kerugian tak berwujud, seperti rasa sakit, dan kualitas hidup.

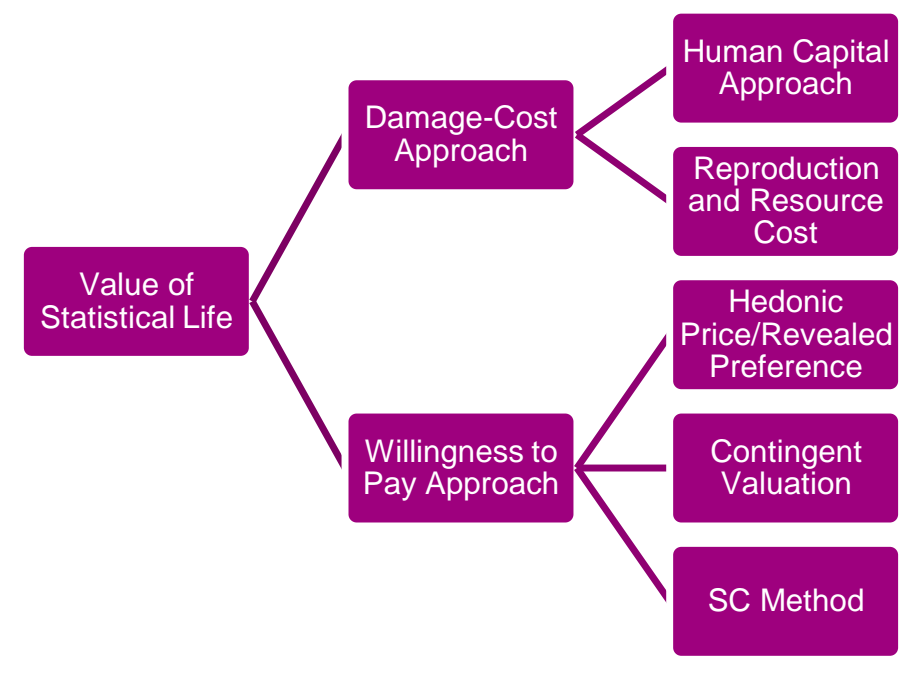

Gambar 1. Metodologi nilai analisis kehidupan statistik

Bahamonde-Birke, Kunert dan Link (2015) membagi metode penghitungan VSL menjadi 2 komponen, yaitu Pendekatan Biaya Kerusakan dan Biaya Reproduksi dan Sumber Daya. Pendekatan Biaya Kerusakan terdiri atas 2 bagian, yaitu pendekatan sumber daya manusia (Human Capital) dan pendekatan reproduksi dan sumber daya. Pendekatan Human Capital menggunakan asumsi bahwa nilai VSL hanya bergantung pada potensi nilai produksi individu di masa depan, yang biasanya diwakili oleh pendapatan kotor seseorang selama masa hidupnya. Pendekatan ini dihitung dengan nilai sekarang, dari pendapatan tenaga kerja yang diharapkan. Metode ini masih digunakan di Indonesia, tetapi di beberapa negara lain telah ditinggalkan, karena hanya menganggap manusia sebagai output dan tidak termasuk faktor kemanusiaan lainnya. Pendekatan Biaya Reproduksi dan Sumber Daya memperhitungkan setiap biaya yang diperlukan untuk kembali ke kondisi semula sebelum kecelakaan terjadi, seperti biaya medis, biaya hukum, dan biaya lainnya, serta biaya sumber daya, termasuk kerugian negara akibat penurunan produktivitas yang disebabkan oleh korban yang terluka. Dengan demikian, metode ini merupakan pengembangan metode modal manusia tetapi belum termasuk preferensi populasi.

\section{METODOLOGI}

Biaya kecelakaan pada suatu daerah dihitung dengan menggunakan 2 pendekatan, yaitu (1) menggunakan Indeks Harga Konsumen atau CPI (Departemen Pekerjaan Umum, 2005); dan (2) menggunakan Indeks Pembangunan Manusia (HDI). Biaya kecelakaan di Kota Bandung pada tahun 2017 berasal dari data pada tahun 2003 dengan asumsi bahwa biaya kecelakaan mengikuti tingkat pertumbuhan rata-rata dari $t$ ke $(t-1)$ :

$$
A C_{i t}=A C_{t-1}(1+g)^{n}
$$

dimana: $A C_{i t} \quad$ : Biaya kecelakaan di Bandung pada tahun observasi (2017)

$A C_{t-1}$ : Biaya kecelakaan di Bandung pada tahun basis (2003)

$g$ : Nilai rata-rata pertumbuhan PDB riil dari tahun $\mathrm{t} k \mathrm{ke}(\mathrm{t}-1)$ 


$$
\begin{gathered}
n \quad: \text { Jumlah tahun dari tahun observasi dan basis } \\
C_{j t}=\left(\frac{C P I_{j t}}{C P I_{i t}}\right) A C_{i t}+3\left(T C_{j h t}\right)
\end{gathered}
$$

dimana: $C_{j t} \quad$ : Biaya kecelakaan pada suatu daerah pada tahun $t$

$C P I_{j t}$ : Indeks harga konsumen pada suatu daerah pada tahun $t$

$C P I_{i t}$ : Indeks harga konsumen pada di kota basis (Bandung) pada tahun basis

$T C_{j h t}$ : Biaya transportasi dari suatu daerah ke rumah sakit pada tahun $t$

$$
C_{j t}=\left(\frac{H D I_{j t}}{H D I_{i t}}\right) A C_{i t}+\left(T C_{j h}\right)
$$

dimana: $H D I_{j t}$ : Indeks Pembangunan Manusia (IPM) di suatu daerah pada tahun $t$

$H D I_{i t}$ : Indeks Pembangunan Manusia (IPM) di suatu daerah dan tahun basis

(Bandung, 2003)

\section{ANALISIS}

\section{Gambaran Keselamatan di Lombok Timur}

Tingkat kecelakaan lalu lintas di IRSMS dibagi menjadi 3 kategori, yaitu kecelakaan fatal, kecelakaan berat, dan kecelakaan cedera ringan. Data yang tercatat di IRSMS, untuk periode 2013 hingga 10 November 2017, adalah 2.249 kejadian kecelakaan. Berdasarkan angka 13, tingkat kecelakaan di Lombok Timur dapat dikategorikan sebagai kecelakaan ringan dengan rata-rata 74 persen dari total kecelakaan.

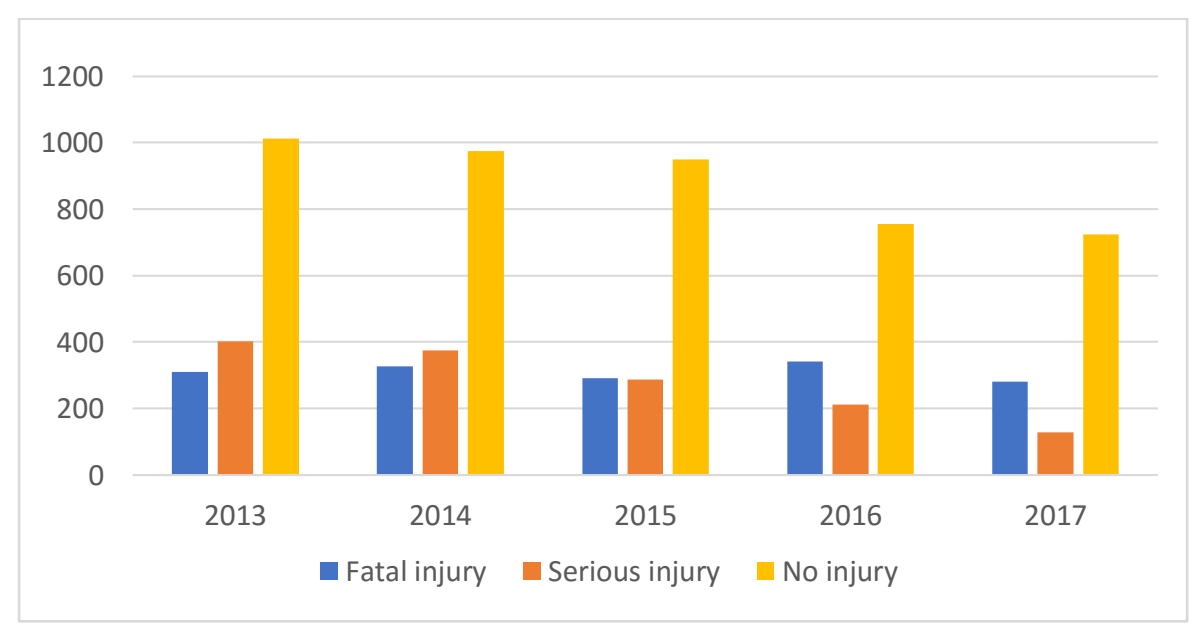

Gambar 2. Jumlah kecelakaan lalu lintas di Lombok Timur tahun 2013 - 2017

Tingkat cedera di IRSMS dibagi menjadi fatal, serius, ringan dan tidak ada cedera. Lebih lanjut cedera ringan adalah jumlah tertinggi yang terlibat dalam kecelakaan lalu lintas di Lombok Timur dengan data sampel 4438 kecelakaan (lihat Gambar 2).

Jenis kendaraan yang terlibat dalam kecelakaan di Lombok Timur dari tahun 2013 hingga tahun 2017 ditunjukkan pada Gambar 3 dan Gambar 4. Data pada Gambar 3 menunjukkan bahwa sekitar $85 \%$ kecelakaan lalu lintas di Lombok Timur tersebut melibatkan sepeda motor. 


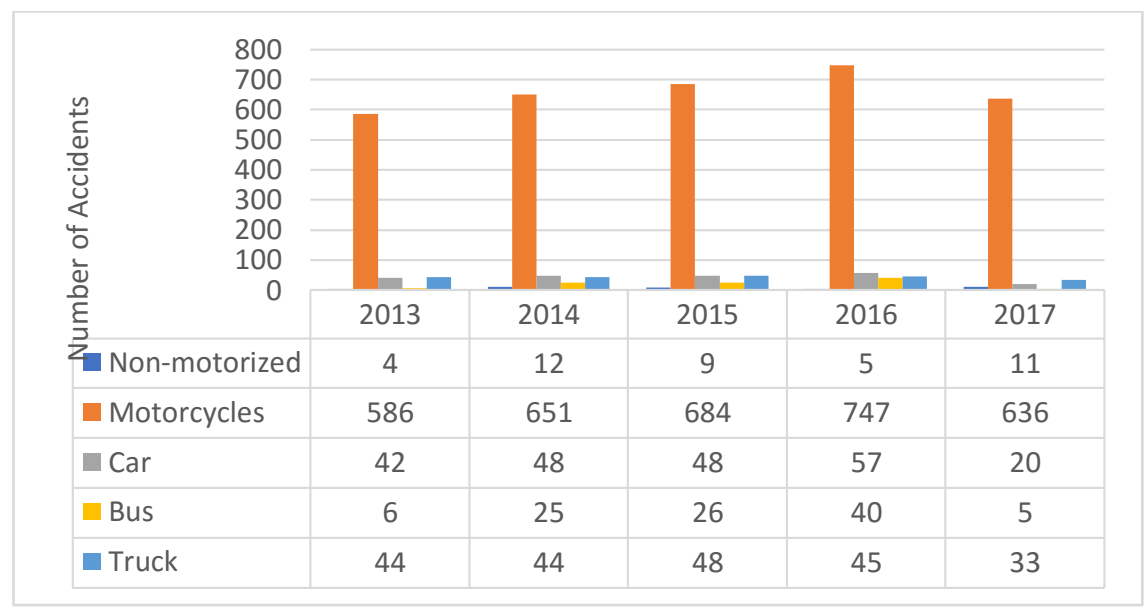

Gambar 3. Jumlah kecelakaan lalu lintas di Lombok Timur menurut jenis kendaraan pada tahun $2013-2017$

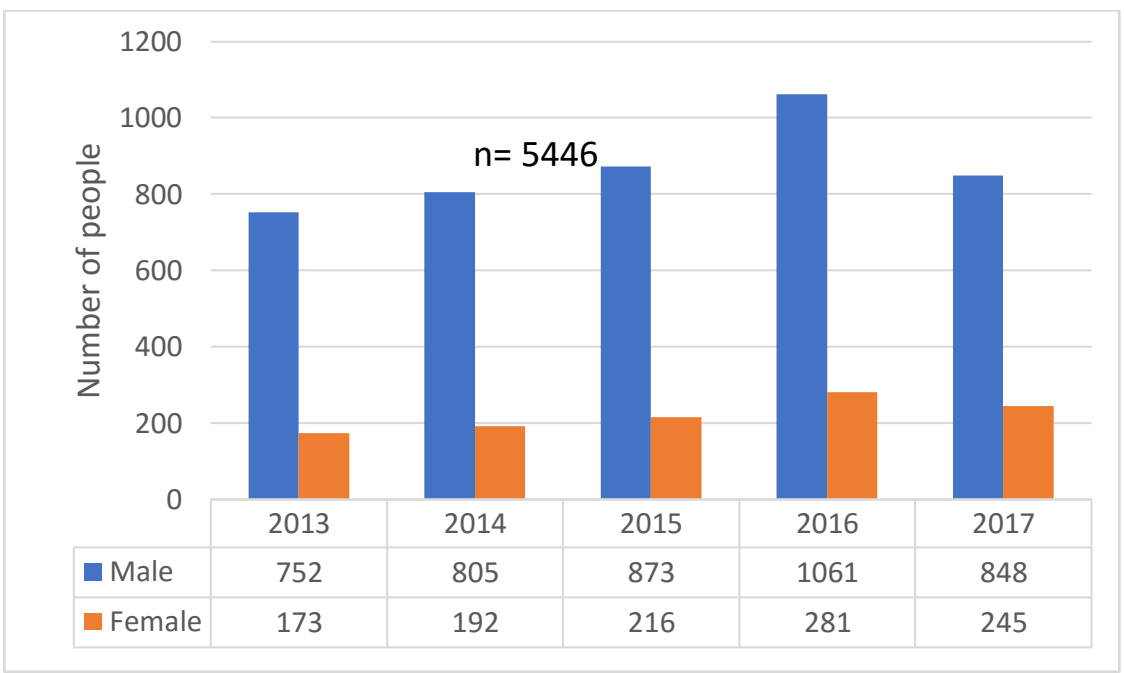

Gambar 4. Jumlah kecelakaan lalu lintas di Lombok Timur menurut jenis kelamin pada tahun $2013-2017$

Pada periode 2013 hingga 2017 (per 10 November 2017), korban yang terlibat dalam kecelakaan lalu lintas di Lombok Timur terdiri atas $80 \%$ laki-laki dan $20 \%$ perempuan, dengan jumlah total 5.446 kejadian. Dimana jumlah penyebab kecelakaan lalu lintas di Lombok Timur dari periode 2013 hingga 2017 (per 10 November 2017) dari sampel 3.726 orang. Sekitar $89 \%$ kecelakaan lalu lintas disebabkan oleh laki-laki dan $11 \%$ disebabkan oleh perempuan., sedangkan korbannya terdiri atas $60 \%$ laki-laki dan $40 \%$ perempuan.

Kelompok usia berkisar 0-4, 5-9, 10-14, 15-19, dan seterusnya hingga 90-94 dengan total data sampel 161 orang. Berdasarkan grafik diatas, kelompok usia tertinggi pada 2013 adalah kelompok usia 10-14 dan 15-19, sedangkan pada tahun 2014 dan 2016 adalah kelompok usia 20-24. Secara rinci, jumlah anak yang mengalami kecelakaan sepanjang periode 2013 hingga 2017 ditunjukkan pada grafik berikutnya. Kita dapat melihat bahwa jumlah anak-anak dari kelompok umur 10-14 adalah yang tertinggi rata-rata dari 2013 hingga 2017 (Gambar 5). 


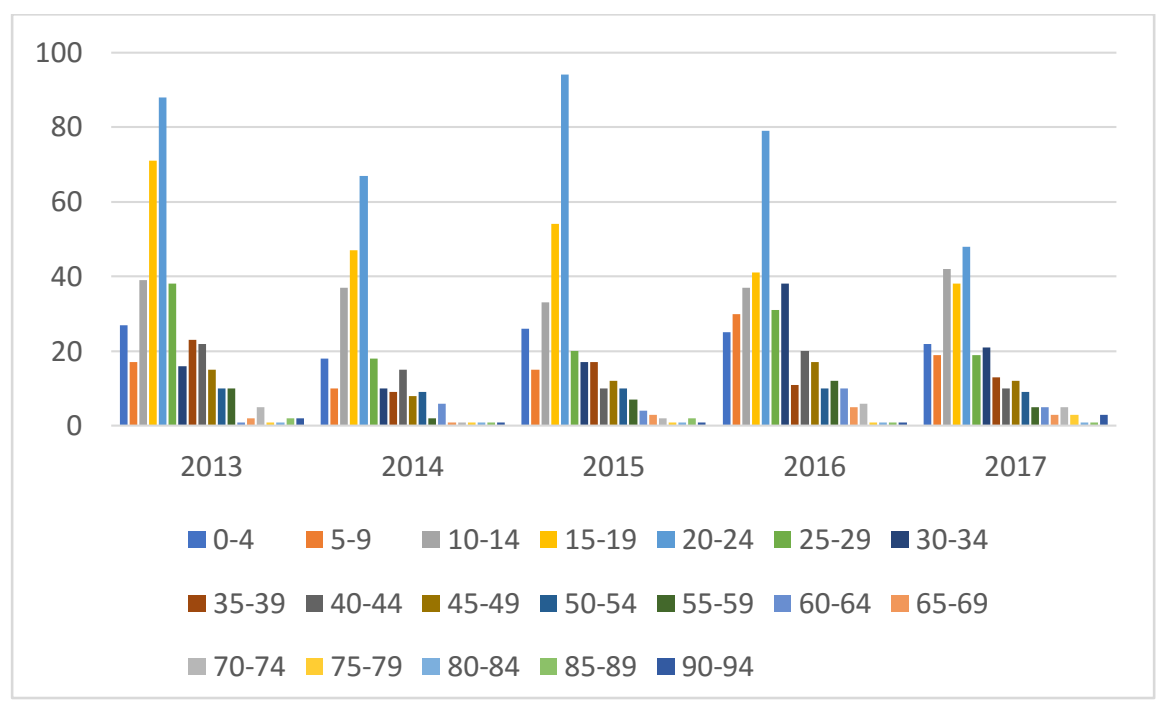

Gambar 5. Jumlah kecelakaan lalu lintas di Lombok Timur menurut kelompok umur

\section{Analisis Biaya Kecelakaan}

Pada bulan Desember 2017, inflasi di Nusa Tenggara Barat tercatat sebesar 0,85 \%, atau terjadi peningkatan Consumer Price Index (CPI) dari 128,79 pada bulan November 2017 menjadi 129,88 pada bulan Desember 2017. Angka inflasi ini berada di atas tingkat inflasi nasional, yang tercatat sebesar $0,71 \%$.

Pada Desember 2017, CPI di Jawa Barat, yang meliputi 7 kota, yaitu Kota Bogor, Kota Sukabumi, Kota Bandung, Kota Cirebon, Kota Bekasi, Kota Depok, dan Kota Tasikmalaya mengalami peningkatan indeks. Pada bulan November 2017, CPI di Jawa Barat adalah 128,16, dan pada bulan Desember 2017 meningkat menjadi 128,88. Dengan kata lain, inflasi di Provinsi Jawa Barat mencapai 0,56\%.

Untuk menghitung biaya transportasi, korban di Bima dan Sumbawa diasumsikan diterbangkan dari kabupaten ke kota Mataram. Tiket penerbangan dari Bima ke Mataram round trip dan biaya hidup untuk keluarga yang mendampingi korban diasumsikan sebesar Rp 4.500.000 per orang, sedangkan dari Sumbawa Besar ke Mataram diasumsikan Rp 3.000.000 per orang. Khusus untuk kasus Kabupaten Lombok Timur, biaya transportasi ke Mataram, termasuk biaya hidup, diasumsikan sebesar Rp 1.000 .000 per orang (pulang pergi).

Analisis biaya kecelakaan atau cedera korban bervariasi sesuai dengan karakteristik wilayah dan jaringan jalan. Penelitian melakukan analisis biaya kecelakaan secara keseluruhan dan pada lokasi spesifik, yakni jalan nasional antar kota atau jalan provinsi. Hasil analisis memperlihatkan biaya kecelakaan pada jaringan jalan nasional antar kota relatif lebih tinggi dibandingkan dengan biaya kecelakaan pada jaringan jalan provinsi. Hal ini dimungkinkan, karena dampak yang lebih besar ditimbulkan oleh kecelakaan pada jaringan jalan nasional antar kota, karena kecepatan lalu lintas yang lebih tinggi dibandingkan dengan kecepatan lalu lintas di jalan provinsi.

Aksesibilitas suatu wilayah terhadap fasilitas kesehatan mempengaruhi biaya korban kecelakaan lalulintas. Pada penelitian ini juga didapat informasi bahwa tingginya biaya korban kecelakaan lalu lintas di wilayah Lombok Timur, disebabkan karena seringkali pengobatan para korban harus dilakukan di tempat yang jauh, bahkan hingga ke Denpasar. 
Penyebabnya adalah fasilitas di rumah sakit daerah yang kurang memadai, sehingga harus dirujuk ke rumah sakit yang lebih besar. Biaya transportasi dan akomodasi yang ditangung oleh Jasa Raharja juga mencakup pengantar atau keluarga korban kecelakaan yang menemani selama proses pengobatan di luar daerahnya.

Tabel 1. Perbandingan biaya cedera korban pada kecelakaan lalu lintas

\begin{tabular}{ccccc}
\hline \multirow{2}{*}{ No. } & Jenis Kecelakaan & \multicolumn{3}{c}{ Biaya Korban Kecelakaan (Rp/korban) } \\
\cline { 3 - 5 } & & Bandung (2003) & $\begin{array}{c}\text { Lombok Timur (2017) } \\
(\text { CPI })\end{array}$ & $\begin{array}{c}\text { Lombok Timur (2017) } \\
(\text { HDI) }\end{array}$ \\
\hline 1. & Fatal & 119.016 .000 & 256.422 .819 & 199.272 .042 \\
\hline 2. & Berat & 5.826 .000 & 15.405 .402 & 10.705 .694 \\
\hline 3. & Ringan & 1.045 .000 & 5.225 .136 & 2.740 .894 \\
\hline
\end{tabular}

Tabel 2. Perbandingan biaya cedera korban pada kecelakaan lalu lintas di Jalan Antar Kota

\begin{tabular}{ccccc}
\hline & & \multicolumn{3}{c}{ Biaya Korban Kecelakaan (Rp/korban) } \\
\cline { 3 - 5 } No. & Jenis Kecelakaan & Bandung (2003) & $\begin{array}{c}\text { Lombok Timur (2017) } \\
(\mathbf{C P I})\end{array}$ & $\begin{array}{c}\text { Lombok Timur (2017) } \\
(\text { HDI) }\end{array}$ \\
\hline 1. & Fatal & 224.541 .000 & 481.119 .019 & 375.069 .054 \\
\hline 2. & Berat & 22.221 .000 & 50.315 .558 & 38.018 .578 \\
\hline 3. & Ringan & 9.847 .000 & 23.967 .387 & 17.404 .389 \\
\hline 4. & Kerugian materi & 8.589 .000 & 21.288 .706 & 15.308 .652 \\
\hline
\end{tabular}

Tabel 3. Perbandingan biaya cedera korban pada kecelakaan lalu lintas di Jalan Provinsi

\begin{tabular}{ccccc}
\hline & & \multicolumn{3}{c}{ Biaya Korban Kecelakaan (Rp/korban) } \\
\cline { 3 - 5 } No. & Jenis Kecelakaan & Bandung (2003) & $\begin{array}{c}\text { Lombok Timur (2017) } \\
\text { (CPI) }\end{array}$ & $\begin{array}{c}\text { Lombok Timur (2017) } \\
\text { (HDI) }\end{array}$ \\
\hline 1. & Fatal & 131.205 .000 & 282.377 .066 & 219.578 .034 \\
\hline 2. & Berat & 18.997 .000 & 43.450 .639 & 32.647 .627 \\
\hline 3. & Ringan & 12.632 .000 & 29.897 .535 & 22.043 .998 \\
\hline 4. & Kerugian materi & 1.572 .500 & 36.483 .513 & 27.196 .712 \\
\hline
\end{tabular}

\section{KESIMPULAN}

Analisis biaya kecelakaan memperlihatkan bahwa biaya kecelakaan bervariasi sesuai dengan tingkat fatalitas dan jenis jalan lokasi terjadinya kecelakaan. Model yang dikembangkan memperlihatkan bahwa angka biaya kecelakaan pada jaringan jalan nasional relatif lebih tinggi dibandingkan yang terjadi pada jaringan jalan provinsi. Hal ini menunjukan bahwa kecelakaan di jalan nasional antar kota mempunyai tingkat fatalitas yang lebih tinggi dibandingkan kecelakaan di jalan provinsi. Fenomena ini dapat saja 
terjadi akibat faktor perilaku berkendara yang agresif. Para pengendara di jaringan jalan nasional antar kota cenderung berkendara dengan kecepatan yang lebih tinggi. Namun untuk melihat hubungan antara variabel kecepatan dengan risiko biaya kecelakaan diperlukan penelitian lebih lanjut.

Tingkat aksesibiltas terhadap fasilitas kesehatan juga mempengaruhi biaya kecelakaan. Masyarakat Lombok Timur relatif lebih sulit mengakses fasilitas kesehatan dibandingkan dengan masyarakat Bandung, sehingga diperlukan biaya transportasi yang lebih besar untuk mengakses fasilitas kesehatan yang memadai. Biaya transportasi yang besar dalam komponen biaya kecelakaan tidak hanya untuk membiayai korban, tetapi juga untuk keluarga yang menemani beserta akomodasinya.

Penelitian ini memperlihatkan bahwa biaya kecelakaan lalu lintas sangat bervariasi, bergantung pada kondisi dan karakteristik daerah tempat kecelakaan lalu lintas tersebut terjadi. Semakin ke arah timur wilayah Indonesia, biaya kecelakaan lalu lintas cenderung relatif lebih tinggi dibandingkan dengan di daerah di bagian barat.

Metodologi ini dapat dikembangkan di seluruh wilayah Indonesia, sehingga nantinya didapat variasi luaran yang dapat digunakan oleh para pemangku kepentingan untuk memprediksi kerugian akibat suatu kecelakaan lau lintas. Dengan menggunakan data kecelakaan lalu lintas yang akurat untuk waktu tertentu, penelitian ini dapat dilanjutkan untuk memprediksi dampak investasi program peningkatan keselamatan jalan terhadap potensi penurunan risiko kecelakaan.

\section{UCAPAN TERIMA KASIH}

Tim peneliti ingin mengucapkan terima kasih kepada Pihak Korlantas POLRI yang sudah memberikan kesempatan untuk mendapatkan dana hibah penelitian keselamatan dan akses terhadap data kecelakaan lalu lintas nasional IRSMS. Penelitian ini juga dilaksanakan pada jalan provinsi di Provinsi NTB, yang sedang melaksanakan proses peningkatan keselamatan yang didanai oleh Kerjasama Indonesia Australia (KIAT).

\section{DAFTAR PUSTAKA}

Bahamonde-Birke, F. J., Kunert, U. and Link, H. (2015) 'The Value of a Statistical Life in a Road Safety Context - A Review of the Current Literature', Transport Reviews. Routledge, 35(4), pp. 488-511.

Departemen Pekerjaan Umum (2005) Perhitungan Besaran Biaya Kecelakaan Lalu Lintas dengan Menggunakan Metoda 'the Gross Output (Human Capital'. Jakarta.

Gitelman, V. and Shalom Hakkert, A. (2011) Economic Evaluation of Road Safety Measures: The Frameworks, Testing and Future Needs, European Union's Transport Policy.

Hauer, E. (1997) Observational Before - After Studies in Road Safety. Pergamon.

Sakhapov, R. and Nikolaeva, R. (2017) 'Economic Aspects of Traffic Safety Administration', in 12th International Conference 'Organization and Traffic Safety Management in Large Cities'. Elsevier.

WHO (2015) Global Road Safety Report. Geneva.

Wijnen, W., Wesemann, P. and de Blaeij, A. (2009) 'Valuation of road safety effects in cost-benefit analysis’, Evaluation and Program Planning, 32(4), pp. 326-331. 
Yahya, M. N. et al. (2013) 'Development of an Integrated Road Safety Management System in Indonesia: Trarfic Police as Lead Agents in a Safe System Approach', Jounal of the Australian College of Road Safety, 24(2). 